\title{
PROFILING POTENTIAL LAND REDISTRIBUTION BENEFICIARIES IN SOUTH AFRICA: IMPLICATIONS FOR AGRICULTURAL EXTENSION AND POLICY DESIGN
}

\author{
Zantsi, S. ${ }^{1}$
}

Correspondence author: S. Zantsi. Email: siphezantsi@yahoo.com

\begin{abstract}
There is a general agreement that land reform has fallen short in achieving its intended objectives. One of the most commonly cited reasons for the slow progress in the land redistribution programme is lack of clear criteria in beneficiary selection. The State Land Lease and Disposal Policy, which is one of the current land redistribution policies, has identified commercial-oriented smallholders in the communal land as one of the land redistribution beneficiaries. However, there is little detailed empirical evidence on their constituents. Such information is crucial for policy-makers including the agricultural extension personnel, as this will enhance effective policy design and appropriate design of extension advisory service which will contribute to the success of land redistribution. The objective of this article is to fill this gap by profiling commercial-oriented small-scale farmers in three provinces that have the highest number of smallholders in South Africa. A survey of 833 farmers from these three provinces was conducted. Descriptive statistics and Binary Logistic Regression were used to analyse the data with the use of STATA software. The results show that a potential emerging farmer is a 55 years old male with primary education. Furthermore, $57 \%$ of the farmers are willing to relocate to commercial farms if there is government support and require an average farm of 152 hectares where they want to plant maize. The article concludes with some recommendations and implications for agricultural extension.
\end{abstract}

Keywords: Aspired farm size, Emerging farmers, Land redistribution, Profile, Willingness to relocate

\section{INTRODUCTION}

\subsection{Background to the problem}

When the first democratic government in South Africa came into power in 1994, a three-legged land reform policy was adopted to remedy the injustices of the past (Hall, 2015). The three legs encompassed restitution (restoring of land to those who were forcefully removed from their land), tenure rights (strengthening of farm workers and people living in the former homelands property rights and redistribution), and correcting the racial skewed land ownership (Department of Land Affairs, 1997). Currently, after more than 20 years of implementing different policies trying to pursue the above pillars, virtually all stakeholders come to the same conclusion: land reform has fallen short in achieving its intended objectives of equity, economic growth, rural development and food security.

\subsection{Description of the problem}

\footnotetext{
1 PhD student, Department of Agricultural Economics, Stellenbosch University, Stellenbosch, South Africa, ORCiD number: 0000-0001-9787-3913, Email: siphezantsi@yahoo.com or siphez@sun.ac.za
} 
This article focusses on the land redistribution leg of the land reform policy. Kepe and Hall's (2018) study shows that only $5.46 \%$ of the 82557220 million hectares $^{2}$ of commercial farmland has been acquired and redistributed through the land redistribution pillar alone. Various reasons have been provided for the unsatisfactory outcomes of the land redistribution. These include lack of post settlement support (Binswanger-Mkhize, 2014; Kirsten et al, 2016), overcrowding in farms acquired through the Settlement Land Acquisition Grant (SLAG) (Kirsten et al, 2016), lack of commercial farming skills among beneficiaries (Dlamini, Verschoor \& Fraser, 2013), commercial farms are too big for the new land reform beneficiaries (Cousins, 2015), poor coordination between government departments (Lahiff \& Li, 2012), insufficient land reform budget, as well as poor and unclear criteria in beneficiary selection (Aliber, 2015; Hall, 2015).

With regards to beneficiary selection, a number of land reform policies including the 1997 White Paper on Land Reform, Land Reform for Agricultural Development (LRAD; 20002010), Pro-Active Land Acquisition Strategy (PLAS; 2006-present), and the State Land Lease and Disposal Policy (SLLDP) of the Department of Rural Development and Land Reform (DRDLR, 2013). The SLLDP has identified commercial-oriented smallholders, both in communal land and private land, as major potential beneficiaries of the land redistribution policy. Furthermore, in support of this view, researchers such as Cousins (2015) have argued that commercial-oriented smallholders are suitable potential beneficiaries of land redistribution. This is because these farmers, against all odds, still farm to obtain a main or an extra source of income.

However, very little is known about these specific potential beneficiaries in the literature. According to Statistics South Africa's (SatsSA, 2016) Community Survey (CS), the majority (more than 60\%) of smallholders are located in three provinces, namely KwaZulu-Natal, the Eastern Cape and Limpopo. While the CS is one of the few national datasets on smallholders in the country, it offers a fair share of information about smallholders, although it does not contain information on the smallholders' intentions with regards to land redistribution and future farming aspirations. With regards to rural households' views on access to land, a national survey reported in Marcus, Eales and Wilchut (1996) showed that the majority of respondents $(67 \%)$ wanted small plots of one hectare and below for residential purpose and a small garden. Again, while this provided some insight into the immediate needs of rural dwellers, it provided little information about commercial-oriented farming households' aspirations to relocate to commercial farms outside the former homelands.

Moreover, Ntsebeza (2002) have partially posed the question of relocating to 26 households in Xhalanga, now known as Sakhisizwe Local Municipality. He asked what the livestock farmers thought would be a solution to their shortage of grazing land and their response was that government should buy or lease the white neighbouring commercial farms for them. Again, the question of relocating was not fully explored as it was not the main focus of the study and, therefore, there is a need to further explore potential land redistribution beneficiaries and their willingness to relocate.

\footnotetext{
${ }^{2}$ Estimated area by Kirsten (2017) using 1993 agricultural census.
} 


\subsection{Objectives}

Against this backdrop, the objective of this study is to fill this gap in literature by providing a detailed profile of potential land redistribution beneficiaries. In doing so, the study addresses the following research questions:

1. What are the demographics of the potential land reform beneficiaries?

2. How many are willing to relocate to commercial farmland and under what conditions are they willing to relocate?

3. What are the factors determining if a farmer will be willing to relocate?

4. What farm size do potential emerging farmers aspire for and what farm activities would they want to pursue if they relocate?

\subsection{Justification and outline}

Answers to these questions are important for policy design, planners and for the agricultural extension staff for a number of reasons. Knowledge of the beneficiary is important for planners to ensure the success of the planned initiatives. This ensures that initiatives are tailored for the needs and circumstances of the beneficiaries. These issues have been prominent in many policies implemented for small-scale farmers in South Africa that failed because of poor understanding of the intended beneficiaries, as argued by Modiselle et al (2005) and Kleinbooi (2013).

\section{LITERATURE REVIEW}

\subsection{Agricultural extension}

Agricultural extension is defined by Davis $(2008: 16)$ as "the entire set of organisations that support and facilitate people engaged in agricultural production to solve problems and to obtain information, skills, and technologies to improve their livelihoods". While there are many typologies of agricultural extension in South Africa (Davis, 2008), the most common type of agricultural extension is the training and visit approach. Furthermore, while there is a growing demand for private agricultural extension services, mainly by commercial farmers, most of the smallholder farmers rely on the government extension services. There are also NonGovernmental Organisations offering agricultural extension services such as Lima Rural Development (Lyne, Jonas \& Ortmann, 2018).

\subsection{Envisaged role of agricultural extension in developing emerging farmers}

The role of agricultural extension in serving emerging farmers is well recognised in literature (Kock \& Terblanche, 2013; Mmbengwa et al, 2009; Van Niekerk et al, 2011). Given the current conditions of emerging farmers, where most are part of the potential land redistribution beneficiaries, it is apparent that as they move from communal farming to commercial farming, they will face a number of challenges. In this regard, the National Development Plan emphasises the need to capacitate agricultural extensionists to serve this group of farmers in order to make a smooth transition to the commercial farming world, and to achieve the objective of the land reform policy of equity, productivity, improved livelihoods and food security (National Planning Commission (NPC), 2011). As such, there are several roles that agricultural extension will have to play in supporting emerging farmers. 
Firstly, the role of agricultural extension service is focussed on managerial aspects of the farm (Swanepoel, Van Niekerk \& Blum, 2016; Zwane \& Kekana, 2014). Van Zyl (1996) has shown evidence from literature that better farm management correlates with larger farms. There is a large difference between smallholder and commercial farm size in South Africa. The smallholder farm size ranges between half a hectare and 20 hectares (Pienaar \& Von Fintel, 2014), while a commercial farm size is on average 2000 hectares (Liebenberg, 2013). This is therefore challenging for emerging farmers and it is one of the cited reasons for the failure of land reform farms (Hebinck, Fay \& Kondlo, 2011).

Secondly, another aspect of agricultural extension is on formalising farm businesses. This includes record keeping, however, most of the emerging farmers in communal land hardly keep records. Record keeping is important for farm business assessment and planning and these records are required by banks in cases of application for credit. The issue of formalising farm business and instilling entrepreneurship was argued by Stevens (2017), where it was acknowledged that there is a need for training in handling administration of the farm business which requires some degree of literacy.

As the farm business grows, effective communication becomes especially important to increase an understanding, cooperation and mutual trust. Some farmers find the transformation from a small informal business to a larger, more formal business structure daunting. Extension should be geared to offer training programmes where farmers are helped to become more aware and understand the transformations required (personal and business transformation) (Stevens, 2017:92-93).

A third critical aspect that emerging farmers would require from agricultural extension is the diffusion of innovation and technology transfer. One of the prerequisites in commercial farming that enables farmers to be competitive is the understanding of current technology and its use (Van Rooyen, 2014). Apart from mechanisation, this includes new seed varieties and pesticides, for example. With regards to diffusion of innovation, this means that agricultural extensionists need to have a complete understanding of their clients (De Beer, 2000).

Lastly, the final important role that agricultural extensionists are required to play in the development of emerging farmers is dissemination of information and marketing skills (Mmbengwa et al, 2009). One of the requirements in commercial farming is to acquire market information and understand their market very well to meet the specifications and be competitive (Mabaya et al, 2011). This calls for one to develop marketing skills, communication and negotiation skills. However, this was found to be lacking in agricultural extension staff (Mmbengwa et al, 2009). Overall, these roles can be achieved only if the extension staff are competent, well equipped and organised.

\subsection{Can the current agricultural extensionists deliver the above roles?}

There is a general agreement that public agricultural extension in South Africa is weak and incompetent (Worth, 2008; Zwane, Groenewald \& Van Niekerk, 2014). There are various assumptions as to what is lacking with government's extension services. In government's own view, much of the problem is too few extension officers, inadequate skills amongst extension officers, and inadequate co-ordination between government and private sector extension services. The issue of fewer extension officers, especially for small-scale farmers, was also prominently found by Lukhalo (2017), while the incompetence of the extension personnel was noted by Zwane et al (2014) in Limpopo Province. 
Another perspective, which government itself has indirectly acknowledged, is the extension methodology, which is dominantly the training and visit approach. In an attempt to address the above challenges of agricultural extension service, the government has implemented programmes to improve the agricultural extension service. These include the Extension Recovery Programme launched in 2008/09 (Department of Agriculture, Forestry and Fisheries (DAFF), 2013), the Strategic Plan for Smallholder Support (DAFF, 2015), and the National Policy on Extension and Advisory Services (DAFF, 2015). However, there is no adequate evidence of success of these programmes in strengthening the public agricultural extension service. Overall, the capability of the current public agricultural extension staff in rendering services that meet the needs of emerging farmers is highly contested (Van Niekerk, Groenewald \& Zwane, 2014).

\subsection{A need for alternative approaches}

In light of the current weak and incompetent public agricultural extension, Farmer Field Schools (FFS) can offer alternative, feasible and cost effective approaches (Duveskog, 2013). The FFS started in Indonesia in the late 1980s, and are a group-based learning process whereby producers meet on a weekly basis at a site they provide, assisted by a facilitator who may or may not be a qualified extension officer (Pontius, Dilts \& Barttlet, 2002). The FFS approach has yielded positive results in many parts of the world, mainly Asia and Africa. Although its application in South Africa has been scarce, recent evidence from Alice in the Eastern Cape has shown that participation in FFS study groups improve farmers' knowledge and yields (Apleni, 2017). This approach could address the challenge of insufficient numbers of extension officers and weak agricultural extension.

Therefore, in order for these roles to be achieved by agricultural extensionists, there needs to be complete understanding of the clients. In other words, knowledge of emerging farmers' background and environment under which they operate their farming (Modiselle et al, 2005). The understanding of the extension clientele is a prerequisite to a successful design of development initiatives, hence there is a need for the present study.

\section{METHODOLOGY}

\subsection{Study area, sample size and data}

This study was conducted in rural parts of three provinces in South Africa, namely the Eastern Cape, KwaZulu-Natal and Limpopo. These provinces were chosen because jointly they house the majority (61\%) of smallholders in the country according to Statistics South Africa's Community Survey in 2016. Therefore, they arguably offer a large pool of potential land redistribution beneficiaries. Within these three provinces, district municipalities which have a high density of smallholders were chosen. According to Aliber and Hart's (2009) analysis of the Income and Expenditure Survey and the Labour Force, the following districts have high a density of smallholders: Amathole, Chris Hani and Oliver Tambo district municipalities (Eastern Cape Province); Umkhanyakude, King Cetshwayo, Harry Gwala and Zulu Land districts (KwaZulu-Natal); and Vhembe (Limpopo Province). A sample of 833 farmers was randomly chosen from the eight districts of the three provinces. Table 1 displays the sample size in each selected district and province. 
Table 1: Summary of sample size per selected district

\begin{tabular}{|l|l|l|l|l|l|}
\hline \multicolumn{2}{|c|}{ Eastern Cape } & \multicolumn{2}{c|}{ KwaZulu-Natal } & \multicolumn{2}{c|}{ Limpopo } \\
\hline District & N & District & N & District & N \\
\hline Amathole & 175 & Umkhanyakude & 125 & Vhembe & 89 \\
\hline Chris Hani & 120 & King Cetshwayo & 80 & & \\
\hline OR Tambo & 84 & Harry Gwala & 56 & & \\
\hline & & Zulu Land & 104 & & $\mathbf{8 9}$ \\
\hline Total & $\mathbf{3 7 9}$ & Total & $\mathbf{3 6 5}$ & Total & \\
\hline
\end{tabular}

Commercial-oriented farmers were randomly selected and interviewed in each of the districts. A semi-structured questionnaire compiled in English and translated into local languages spoken in the study areas was used for the interviews with farmers.

\subsection{Variable selection and data analysis methods}

According to Modiselle et al (2005), production and investment decisions in smallholder farming are not only determined by economic factors and availability of natural resources, but by a range of factors including social, economic, biological and institutional factors in which the farmer operates. Thus, background of the farmer with regards to production and aspirations are important determinants of decision making and in turn affects production (Chipfupa \& Wale, 2018). In the case of the Land Redistribution Programme, these factors seem to be underappreciated by policy-makers and a top-down approach is often followed. A selection of the variables used in this study was influenced by the above background, hence socioeconomic, production and aspiration variables were mainly chosen.

Mostly descriptive statistics, tables and charts were used together with Binary Logistic Regression. Binary Logistic Regression is used to analyse the relationship between multiple independent variables and a dependent categorical variable. In this study, a Binary Logistic Regression was chosen since the dependent variable has only two outcomes, namely willing or not willing to relocate to a commercial farm. The cumulative logistic probability model is econometrically specified in Equation 1 (Gujarati, 1995):

$\mathrm{L}=\mathrm{Ln}[\mathrm{P} /(1-\mathrm{P})]=,\alpha_{0}+\alpha_{\mathrm{n}} \mathrm{X}_{\mathrm{n}}+, \ldots, \alpha_{\mathrm{n}} \mathrm{X}_{\mathrm{n}}+\beta_{1}, \mathrm{D}_{1}, \ldots+\beta_{\mathrm{n}} \mathrm{D}_{\mathrm{n}}+\mathrm{e}$

Where,

$\mathrm{I}=$ Household $_{\mathrm{i}}=1,2, . ., \mathrm{n}$

$\mathrm{Ln}=\mathrm{Log}$ of the odds ratio

$\mathrm{P}=$ Probability that a household is willing to relocate to a commercial farm

1- $\mathrm{Pi}=$ Probability that a household is not willing to relocate to a commercial farm

$\alpha_{1} \ldots \alpha_{n}=$ Coefficients of explanatory variables $\left(X_{1}, . ., X_{n}\right)$

$\beta_{1 \ldots} \beta_{\mathrm{n}}=$ Coefficient of explanatory dummy variable

$\mathrm{e}=$ an error term

\section{RESULTS AND DISCUSSION}

\subsection{Socio-economic information of the farmers}

The sample of this study consisted of $61 \%$ males and $39 \%$ females (Figure 1). This is consistent with the literature (Aliber \& Hart, 2009). The average age of the household head was 55 years old where the oldest respondent was 86 years and the youngest was only 21 years old with a 
deviation of 11.42 from the mean. These results are not far off from the smallholder Community Survey, which reported an average age range of 45-54 years (StatSA, 2016). Furthermore, Sinyolo, Mudhara and Wale (2016) have also found similar results in KwaZuluNatal. Moreover, these results show that the potential emerging farmer is on average four years younger than his commercial counterpart (DAFF, 2017).

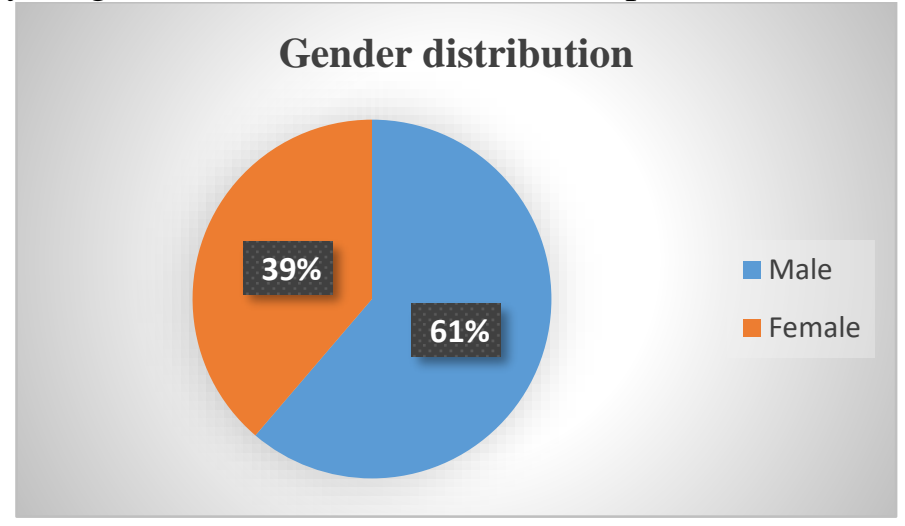

\section{Figure 1: Gender distribution}

In terms of education, which is one of the important variables for planning and designing extension service, it was found that most farmers have primary and secondary education, while few claimed to have tertiary level (Figure 2). It is also interesting to note that a fair share of potential emerging farmers have no formal education at all.

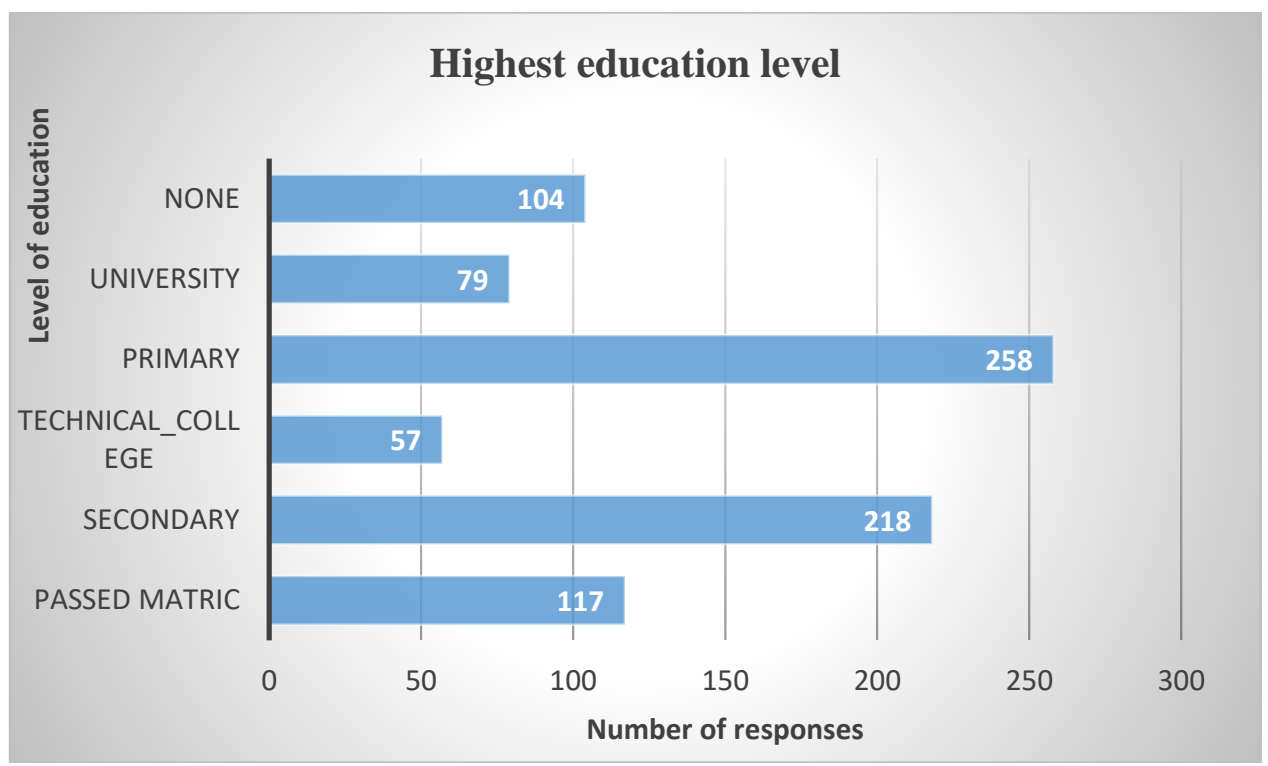

Figure 2: Distribution of education level of the farmer

The income in the study sample was not uniformly distributed. The household with the highest monthly income had R66 000 while the lowest income was R1200. It is clear that there is high income inequality in the sample, however, it is not unique to the study areas, but cut across the whole country. As such, South Africa is among one of the highest income inequality countries in the world (Keeton, 2014). Households in the sample obtain their income from a variety of sources ranging from farming to non-farm and off-farm sources as depicted in Figure 3. The majority $(32 \%)$ of households obtained their primary income from crop sales followed by old 
age grants and salaries, while a small proportion obtained their income from other forms of grants such as foster care and disability grants.

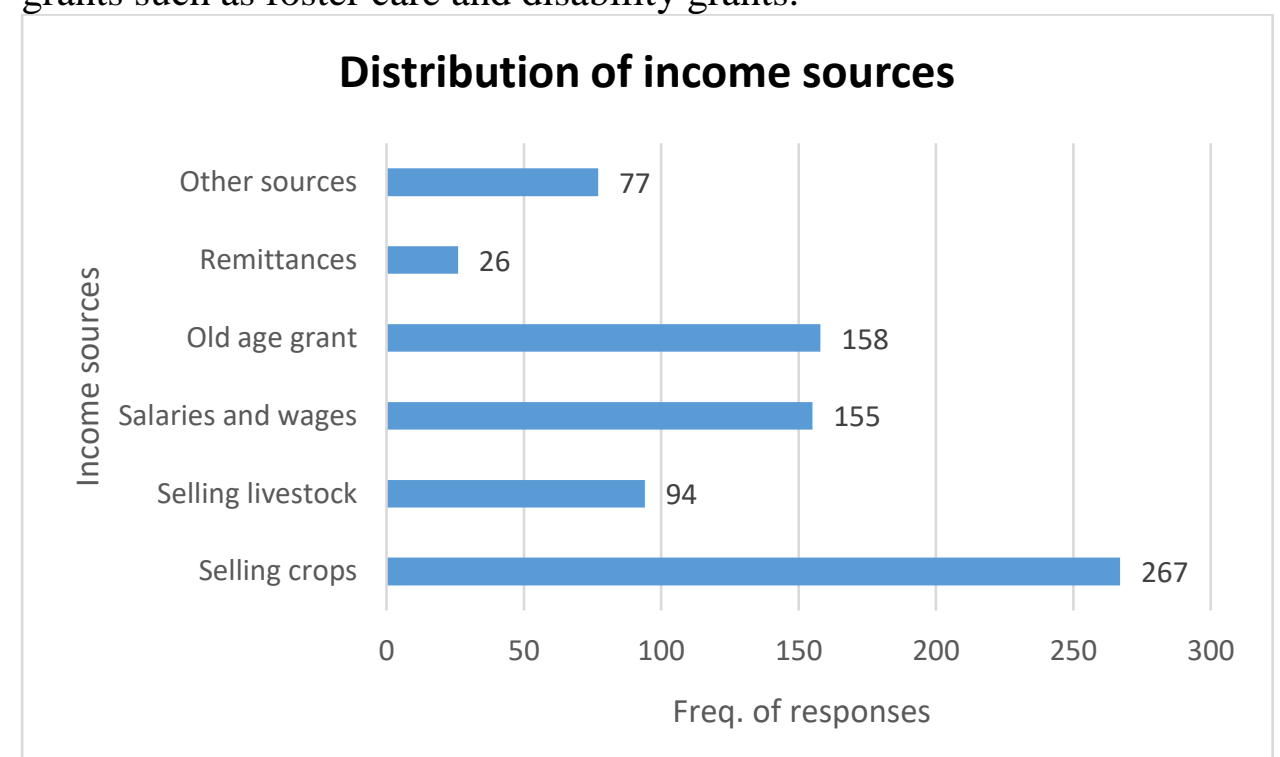

\section{Figure 3: Distribution of income sources}

\subsection{Willingness to relocate}

Whilst the aspirations of smallholders have been taken into account by some studies (Chipfupa \& Wale, 2018; Mearns, 2011; Nieuwoudt, 2000; Senyolo, 2007), few have partly considered whether smallholders would be willing to move from their communal farm, and if so, under what circumstances (Ntsebeza, 2002). It is assumed that they would be willing to participate in land reform projects given the constraints faced by them, such as limited access to capital due to insecure property rights (Cousins, 2015), high transaction costs (Khapayi \& Celliers, 2016), smallholding size (Fourie, Mahlako \& Van Der Westhuizen, 2018) and the overutilization of shared rangeland (Vetter, 2003). In this study, respondents were asked whether they feel constrained by these factors.

The majority (57\%) indeed felt constrained by farming in the homelands citing a variety of reasons such as land shortage, both for grazing and arable land, as well as drawbacks of unsecure property rights as they have no title deeds on the land they are currently using which they can use to secure loans from the private commercial banks. With regards to shortage of land, this finding is interesting concerning the overwhelming literature on abandoned arable field cultivation in most rural former homelands of the country (Andrew \& Fox, 2004; Connor \& Mtwana, 2017; De La Hey \& Beinart, 2017).

While the majority felt constrained, a small proportion (32\%) did not share the same sentiment and others were not sure about how they felt, claiming they have never thought about it (Figure 4). However, they did share sentiments about poor and/ or lack of agricultural support from the government including agricultural extension service. 


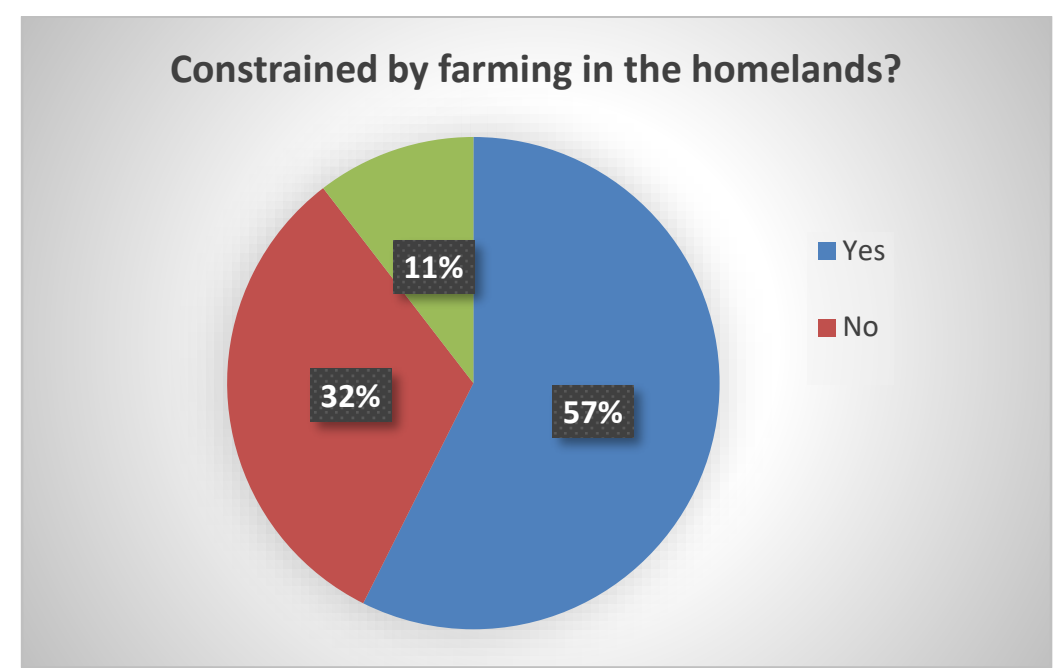

\section{Figure 4: Farmers' perception of communal land farming}

For the total sample, just over half of the respondents (57\%) were willing to relocate, while the remaining $43 \%$ were not willing. Furthermore, in terms of provinces, in the Eastern Cape, $72 \%$ were willing to relocate and only $28 \%$ were not. In KwaZulu-Natal, there was only a slight difference between those willing to relocate and those who were not. In Limpopo, $51 \%$ were not willing to relocate, while $49 \%$ were willing.

Moreover, to take this discussion a step further, respondents were asked an open ended question as to under which conditions they would be willing to relocate. The majority (43\%) were not interested in relocating at all, while $35 \%$ were willing to relocate if there is government support which is what is currently happening with the land redistribution pillar. Of interest is the minority group of $22 \%$ who are willing to move even if it means they have to rent land as shown in Figure 5. The other interesting feature about this group is that they also express that they only need land, then they will be able to finance production going forward.

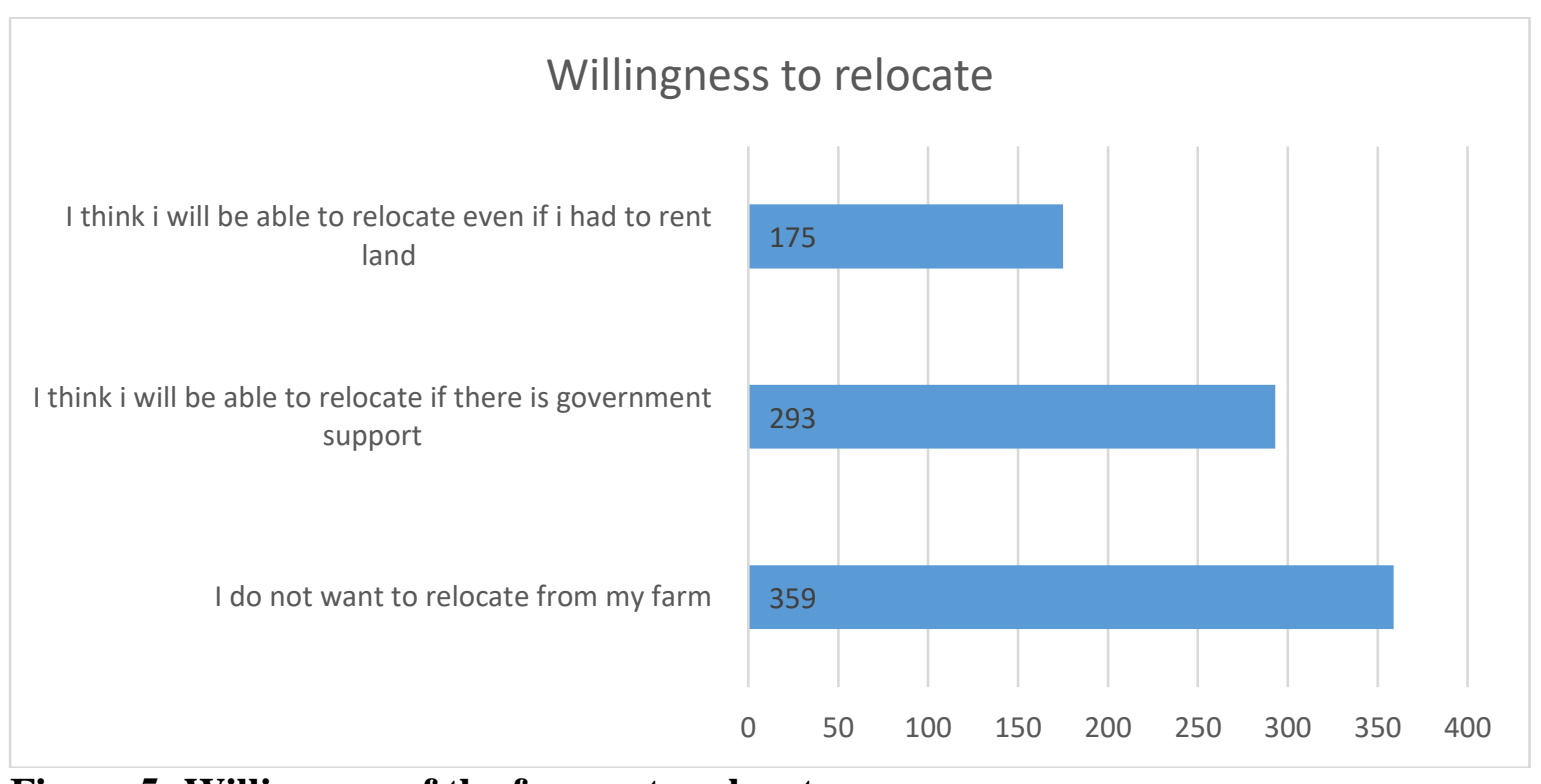

Figure 5: Willingness of the farmer to relocate 


\subsection{Determinants of willingness to relocate}

While it is assumed that potential emerging farmers aspire to take their farming operations a step further and move to commercial farming so as to improve their livelihoods, not much is known about what factors would determine if they would want to relocate or not. Van Rooyen and Njobe-Mbuli (1996), drawing from international experience of land reform, suggested factors that should be considered in selecting potential emerging farmers for a productivity based land redistribution programme. The factors they suggested were age of the farmer, education level, and net worth, which in this study sample, the variable of 'total household income' could be taken as proxy for net worth. Furthermore, Sihlobo and Kirsten (2018) recently emphasised the importance of a proper beneficiary selection framework and again touched on the above points.

The results of the Binary Logistic Regression of the present study are presented in Table 2 and indicate that these three factors are statistically significant determinants of relocation. With regards to age, while an average farmer in South Africa is in the late-middle age category, the potential land reform beneficiaries would need not to be too old for a sustainable land reform. This is particularly true given the low levels of youth participation in agriculture. Furthermore, it has been a concern of the provincial departments of rural development and land reform to ease pressure on the communal grazing lands by considering communal farmers owning large herds and flocks of livestock. Following this objective, it was expected that the number of animals owned would be a significant determinant of the willingness to relocate. However, both large stock and small stock livestock widely kept in communal areas showed a negative relationship to the dependent variable.

While education is important in doing business negotiations, current results showed a different picture. Although 'Passing matric' is statistically significant, the relationship to the dependent variable (willingness to relocate) is negative. Surprisingly, 'no formal education' shows a positive correlation and is significant albeit at $90 \%$ confidence interval. This might be a result of tacit knowledge of farming generated over the years as it has been shown that the majority of farmers were relatively nearing pension.

The capacity to aspire is sometimes related to one's proximity to their role models. Two KwaZulu-Natal district municipalities, King Cetshwayo and Zulu Land, show a positive correlation and were statistically significant. This brings to attention that location of the farmer influences his/her farming aspirations, for example, close proximity of potential emerging farmers to commercial farms could influence their farming aspirations.

Household income is also a significant determinant of willingness to relocate. This is important because relocation implies cost and as such it will be difficult for low income households for a couple of reasons. Firstly, farming is a risky business and returns do not come immediately. Secondly, post settlement support takes some time while households need to incur living costs. This might be made even more difficult by poor network or extended family ties as it is likely that the farm will be far away from the original home of the household beneficiary. 
Vol. 47 No. 4, 2019: 135 - 151

http://dx.doi.org/10.17159/2413-3221/2019/v47n4a532

Table 2: Results of Binary Logistic Regression

\begin{tabular}{|c|c|c|c|c|}
\hline Variable name ${ }^{3}$ & Odds ratio & Std. Err. & Coef. & $\mathbf{p}>\mathbf{z}$ \\
\hline Age in years & $1.048933 * * *$ & .0102216 & .043 & 0.000 \\
\hline Total household income (monthly) (R) & $1.000019 *$ & .0000104 & .000 & 0.068 \\
\hline Total number of cattle owned & .9983799 & .0027746 & -.001 & 0.560 \\
\hline Total number of goats owned & .9993264 & .0036348 & -0.000 & 0.853 \\
\hline Total number of sheep owned & .9970982 & .0022249 & -.002 & 0.193 \\
\hline No formal education & $1.695874 *$ & .5172608 & .528 & 0.083 \\
\hline Pass matric & $.4149815 * * *$ & .1289567 & -.879 & 0.005 \\
\hline Primary & .8205271 & .1784712 & -.197 & 0.363 \\
\hline Technical college & .6207202 & .222626 & -.476 & 0.184 \\
\hline University degree & .8543109 & .2595785 & -.157 & 0.604 \\
\hline Amathole & 1.695874 & .3279707 & .026 & 0.934 \\
\hline Chris Hani & 1.431557 & .527596 & .358 & 0.330 \\
\hline Harry Gwala & 1.813837 & .6923323 & .595 & 0.119 \\
\hline King Cetshwayo & $2.046289 * *$ & .7014578 & .716 & 0.037 \\
\hline OR Tambo & .7509516 & .2871573 & -.286 & 0.454 \\
\hline Vhembe & 1.218096 & .4141198 & .197 & 0.562 \\
\hline Zulu Land & $3.535847 * * *$ & 1.21111 & 1.26 & 0.000 \\
\hline Constant & .049 & .545 & -3.01 & 0.000 \\
\hline Number of observations & 718 & & & \\
\hline Prob $>$ chi $^{2}$ & .0000 & & & \\
\hline Pseudo $\mathrm{R}^{2}$ & 0.095 & & & \\
\hline Log likelihood & -437.14 & & & \\
\hline
\end{tabular}

Notes: $*=\mathrm{P}<0.10, * *=\mathrm{P}<0.05$ and $* * *=\mathrm{P}<0.01$

\subsection{Land demand and aspired farming activities}

One of the reasons cited for the poor performance of the redistributed land reform farms is that the current commercial farms are too large for emerging farmers (Cousins, 2015). However, it is not known how big or small should the land reform farms be to best suit and enable the potential of emerging farmers. In an attempt to gain insight on this issue, respondents who claimed to be willing to relocate were asked what farm size they require and what farming

\footnotetext{
3 Two dummy variables, namely 'Secondary education' and 'Umkhanyakude district' were omitted for collinearity.
} 
activities they would want to pursue once they have relocated. A variety of farm sizes were given by the respondents, with the smallest farm size being 3 hectares and the biggest being 5000 hectares. The average farm size was 152 hectares. The majority (49\%) of respondents wanted a farm between one and 51 hectares, while $29 \%$ wanted a farm between 100 and 200 hectares. Only $15 \%$ wanted a slightly bigger farm size between 300 and 350 hectares as shown in Figure 6. Although different land potentials in the interviews were not taken into account, these results indeed show that the current commercial farms are beyond the aspirations of the potential emerging farmers.

Observations from the interviews have shown that some respondents, particularly in the Eastern Cape, were not familiar with the quantification of farm size into hectares. For those who wanted to pursue livestock if they relocate, some cited smaller farm size such as 10 hectares, while they own a relatively larger herd/flock. This shows a lack of understanding of rangeland management. Furthermore, it is clear that the gap between the average potential emerging farm and current commercial farm is arguably too wide. Liebenberg (2013), using agricultural census data, found that the average commercial farm size is 2000 hectares and it is possible that this figure has increased as the number of commercial farmers has further decreased from 39000 to about 35000 (DAFF, 2017).

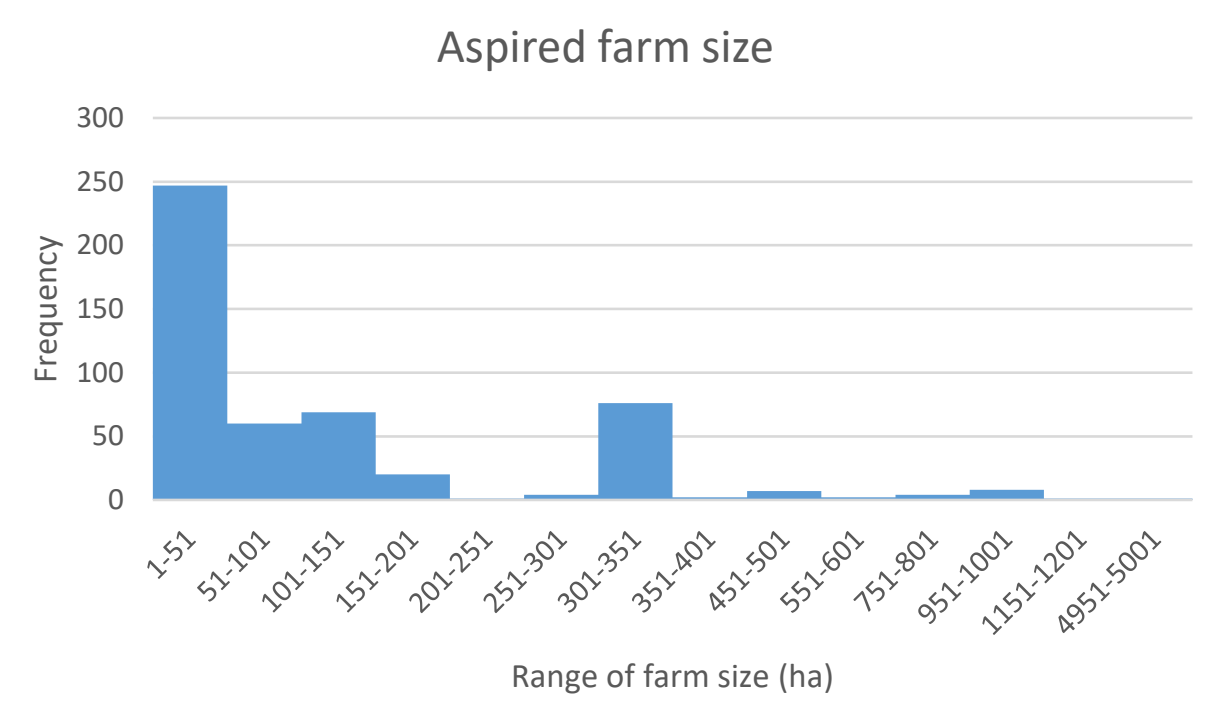

Figure 6: Histogram showing aspired farm sizes

In terms of aspired farming activities, Figure 7 provides a summary of the responses, with the majority $(56 \%)$ of the respondents wishing to plant maize and $15 \%$ wishing to plant vegetables. These results are in line with Mearns' (2011) results about a potential SLAG group who had submitted a proposal for funding in Mpumalanga in 2002. About $15 \%$ had an interest of pursuing small stock farming and $8 \%$ wanted to venture into dairy farming. However, in terms of livestock activities, Mearns' (2011) results showed that respondents wanted to farm with beef cattle, although many had not owned cattle. What was clear in the case of this study, is that most of these activities were related to what the farmers were currently doing on their farms, except for dairy farming. This shows that most of the land reform beneficiaries will have to start new farming activities. This will be accompanied by a risk as farmers will have to learn new methods of farming with the new farming activity. In this regard, extensionists will have to play a role in knowledge transfer. This is perhaps the reason for why most of the farmers 
want to continue with the same farming activities and eliminate the risk and cost of learning new farming methods.

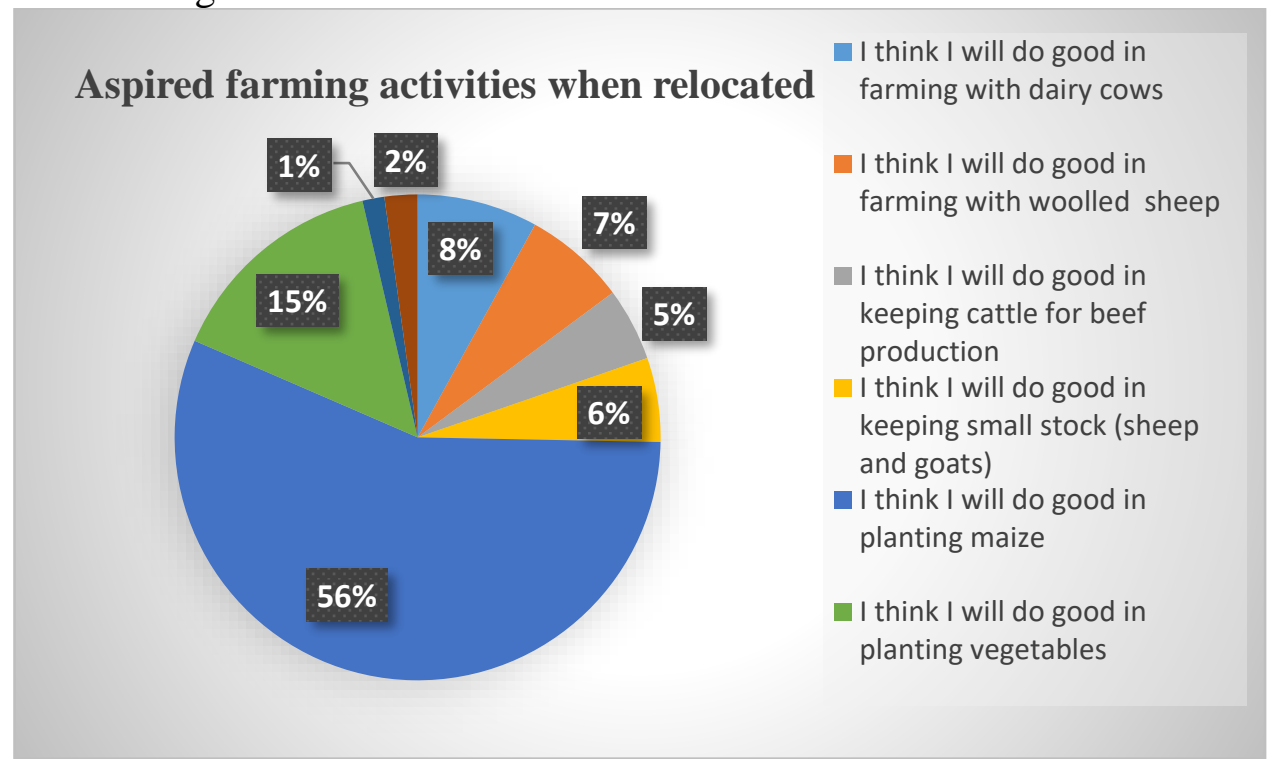

Figure 7: Aspired farming activities when relocated

\section{CONCLUSION, IMPLICATIONS FOR EXTENSION AND RECOMMENDATIONS}

\subsection{Conclusion}

The objective of this article was to contribute to the scant literature on the constituents of potential land redistribution beneficiaries currently farming in communal land. Three provinces which jointly house more than $60 \%$ of smallholders in the country were chosen. The results show that a potential emerging farmer is a 55 year old male with low education level, mostly primary or secondary education. Most obtain their primary income from the selling of crops. Furthermore, more than half of the sample felt constrained by farming in communal land, citing several reasons therefore, including the inadequate land. Nevertheless, about half of the respondents were willing to relocate to commercial farms on condition of full government support including agricultural extension.

Results of the Binary Logistic Regression confirm suggestions of Van Rooyen and NjobeMbuli (1996) and Sihlobo and Kirsten (2018) that age, household income and education are three of the most important factors to be considered in the selection criteria as they have also shown to be significant determinants of the willingness to relocate. The average desired potential emerging farm size is much smaller than the current commercial farm size. Potential emerging farmers want to farm with maize, vegetables and small stock when they relocate to commercial farms.

\subsection{Implications for extension and recommendations}

Based on the results of this study, it is clear that agricultural extension will have to play a major role in the development of emerging farmers as envisaged in the NDP in order to achieve a successful land redistribution. As such, agricultural extension services should be aligned with the needs of emerging farmers. The following factors should be considered:

- Transfer of knowledge should be at a level appropriate for the low levels of literacy. 
- Efforts should be made to subdivide the existing commercial farms to suit emerging farmers' potential, or multi-enterprise large-farm management skills should be put in place by extensionists and be transferred to emerging farmers.

- Appropriate training of rangeland management will be required for the potential emerging farmers to ensure sustainable use of natural resources to avoid rangeland degradation.

- Since an average potential emerging farmer is 55 years old, the long lease agreement in the SLLDP needs rethinking for sustainability purposes.

\section{ACKNOWLEDGEMENT}

The financial assistance of the National Research Foundation (NRF) towards this research is hereby acknowledged. Opinions expressed, and conclusions arrived at, are those of the authors and are not necessarily to be attributed to the NRF.

\section{REFERENCES}

ALIBER, M., 2015. Unravelling the willing buyer/willing seller question. In Land divided, land restored. Land reform in South Africa for the 21 st century. Johannesburg: Jacana.

ALIBER, M. \& HART, T.G.B., 2009. Should subsistence farming be supported as a strategy to address rural food insecurity? Agrekon, 48(4):434-458.

ANDREW, M. \& FOX, R.C., 2004. 'Undercultivation' and intensification in the Transkei: A case study of historical change in the use of arable land in Nompa, Shixini. Dev. South. Afr., 21(4):687-706.

APLENI, A., 2017. The impact of the farmer field school approach on small-scale vegetable farmers' knowledge, agency and production in Alice, Eastern Cape, South Africa. M.Agric Thesis, University of Fort Hare.

BINSWANGER-MKHIZE, H.P., 2014. From failure to success in South African land reform. Afr. J. Agr. Resour. Econ., 9(4):253-269.

CHIPFUPA, U. \& WALE, E., 2018. Explaining smallholder aspirations to expand irrigation crop production in Makhathini and Ndumo-B, KwaZulu-Natal, South Africa. Agrekon, 57(3-4):284-299.

CONNOR, T. \& MTWANA, N., 2017. Vestige garden production and deagrarianisation in three villages in the Eastern Cape, South Africa. S. Afr. Geogr. J., 100(1):82-103.

COUSINS, B., 2015. Through a glass, darkly: Towards agrarian transformation in South Africa. In Land divided, land restored. Land reform in South Africa for the 21 st century. Johannesburg: Jacana.

DAVIS, K., 2008. Extension in Sub-Saharan Africa: Overview and assessment of past and current models, and future prospects. JIAEE., 15(3):15-28.

DE BEER, L., 2000. The specialist or generalist: What does the year 2000 and beyond require for sustainable agricultural development? S. Afr. J. Agric. Ext., 29(1):58-72.

DE LA HEY, M. \& BEINART, W., 2017. Why have South African smallholders largely abandoned arable production in fields? A case study. J. South. Afr. Stud., 43(4):753-770.

DEPARTMENT OF LAND AFFAIRS, 1997. White paper on South African land policy. Available from: $\quad$ www.ruraldevelopment.gov.za/phocadownload/White- 
Papers/whitepaperlandreform.pdf

DEPARTMENT OF AGRICULTURE, FORESTRY AND FISHERIES (DAFF), 2013. Strategic plan for smallholder support. Available from: https://www.nda.agric.za/doaDev/sideMenu/SmallHolder/docs/Strategic\%20Plan\%20fo r\%20Smallholder\%20Support.pdf

DEPARTMENT OF AGRICULTURE, FORESTRY AND FISHERIES (DAFF), 2015. National policy on extension and advisory services. Available from: https://pmg.org.za/committee-meeting/20459/

DEPARTMENT OF AGRICULTURE, FORESTRY AND FISHERIES (DAFF), 2017. Abstract of agricultural statistics. Available from: https://www.daff.gov.za/Daffweb3/Portals/0/Statistics\%20and\%20Economic\%20Analy sis/Statistical\%20Information/Abstract\%202017.pdf

DEPARTMENT OF RURAL DEVELOPMENT AND LAND REFORM (DRDLR), 2013. State land lease and disposal policy. Available from: www.ruraldevelopment.gov.za/phocadownload/Policies/state land_lease and disposal _policy_25july2013.pdf

DLAMINI, T.S., VERSCHOOR, A.J. \& FRASER, G.C., 2013. Exploring options in reforming South African land ownership: Opportunities for sharing land, labour and expertise. Agrekon, 52(1):24-45.

DUVESKOG, D., 2013. Farmer field schools as a transformative learning space in the rural African setting. Doctoral Thesis, Swedish University of Agricultural Sciences.

FOURIE, P.J., MAHLAKO, S.R. \& VAN DER WESTHUIZEN, C., 2018. Assessment of the management practices of emerging sheep production systems in the eastern Free State: Can the extensionist make a difference? S. Afr. J. Agric. Ext., 46(2):57-68.

GUJARATI, D.N., 1995. Basic Econometrics. $3^{\text {rd }}$ ed. New York: McGraw-Hill.

HALL, R., 2015. Who, what, where, how, why? The many disagreements about land redistribution in South Africa. In Land divided, land restored. Land reform in South Africa for the 21 st century. Johannesburg: Jacana.

HEBINCK, P., FAY, D. \& KONDLO, K., 2011. Land and agrarian reform in South Africa's Eastern Cape Province: Caught by continuities. J. Agrar. Change, 11(2):220-240.

KEETON, G., 2014. Inequality in South Africa. J. HSF., 74(1):26-31.

KEPE, T. \& HALL, R., 2018. Land redistribution in South Africa: Towards decolonisation or recolonisation? Politikon, 45(1):128-137.

KHAPAYI, M. \& CELLIERS, P.R., 2016. Factors limiting and preventing emerging farmers to progress to commercial agricultural farming in the King William's Town area of the Eastern Cape Province of South Africa. S. Afr. J. Agric. Ext., 44(1):25-41.

KIRSTEN, J.F., MACHETHE, C.L., NDLOVU, T. \& LUBAMBO, P., 2016. Performance of land reform projects in the North West Province of South Africa: Changes over time and possible causes. Dev. South. Afr., 33(4):442-458.

KLEINBOOI, K., 2013. Land reform, tradition and securing land for women in Namaqualand. In In the shadow of policy. Johannesburg: Wits University Press.

KOCH, B.H. \& TERBLANCHE, S.E., 2013. An overview of agricultural extension in South 
Africa. S. Afr. J. Agric. Ext., 41(1):107-117.

LAHIFF, E. \& LI, G., 2012. Land redistribution in South Africa: A critical review. Working Paper 80874. World Bank. Washington, D.C., United States of America.

LIEBENBERG, F., 2013. South African agricultural production, productivity and research performance in the $20^{\text {th }}$ century. PhD Thesis, University of Pretoria.

LUKHALO, T., 2017. An expenditure review of agricultural extension system in South Africa. Masters Thesis, University of Pretoria.

LYNE, M.C., JONAS, N. \& ORTMANN, G.F., 2018. A quantitative assessment of an outsourced agricultural extension service in the Umzimkhulu District of KwaZulu-Natal, South Africa. J. Agric. Educ. Ext., 24(1):51-64.

MABAYA, E., TIHANYI, E., KARAAN, M. \& VAN ROOYEN, J., 2011. Case studies of emerging farmers and agribusiness in South Africa. Stellenbosch: Sun Press.

MARCUS, T., EALES, K. \& WILCHUT, A., 1996. Down to earth: Land demand in the new South Africa. Durban: Indicator Press.

MEARNS, K.F., 2011. Ekaluka farmers' association and the land reform programme: Expectations and success factors. Dev. South. Afr., 28(2):241-254.

MMBENGWA, V.M., GUNDIDIZA, M., GROENEWALD, J.A. \& VAN SCHALKWYK, H.D., 2009. Factors affecting extension workers in their rendering of effective service to pre and post-settled farmers in government initiated and supported farming small, micro and medium enterprises. S. Afr. J. Agric. Ext., 38:1-14.

MODISELLE, S., VAN ROOYEN, C.J., LAURENT, C., MAKHURA, M.T., ANSEEUW, W. \& CASTERNS, J., 2005. Towards describing small-scale agriculture: An analysis of diversity and the impact thereof in the Lielifontein area (Northern Cape, South Africa). S. Afr. J. Agric. Ext., 34(2):303-317.

NATIONAL PLANNING COMMISSION (NPC), 2011. The national development plan 2030: Our future - make it work. Available from: https://www.gov.za/sites/default/files/gcis_document/201409/ndp-2030-our-futuremake-it-workr.pdf

NIEUWOUDT, W.L., 2000. An economic evaluation of a crop insurance programme for smallscale commercial farmers in South Africa. Agrekon, 39(3):269-291.

NTSEBEZA, L., 2002. Cattle production in Xhalanga district. In Cattle ownership and production in the communal areas of the Eastern Cape Province, South Africa (pp.4658). PLAAS Research Report No. 10. Belville, South Africa.

PIENAAR, L. \& VON FINTEL, D., 2014. Hunger in the former apartheid homelands: Determinants of convergence on a century after the 1913 land act. Agrekon, 53(4):38-67.

PONTIUS, J., DILTS, R. \& BARTTLET, A., 2002. From farmer field school to community IPM. Bangkok: Food and Agricultural Organization.

SENYOLO, G.M., 2007. Factors distinguishing low turnover emerging farmers from high turnover emerging farmers in South Africa. MSc Thesis, University of Limpopo.

SIHLOBO, W. \& KIRSTEN, J.F., 2018. Clear criteria needed for beneficiary selection in South Africa's agricultural land redistribution. Available from: 
www.businesslive.co.za/bd/opinion/2018-06-25-clear-criteria-needed-for-beneficiaryselection-in-agricultural-restitution. On 15 September 2018.

SINYOLO, S., MUDHARA, M. \& WALE, E., 2016. To what extent does dependence on social grants affect smallholder farmers' incentives to farm? Evidence from KwaZulu-Natal, South Africa. Afr. J. Agr. Resour. Econ., 11(2):154-165.

STATISTICS SOUTH AFRICA (StatsSA), 2016. General household survey. Available from: http://www.statssa.gov.za/?p=9922

STEVENS, J.B., 2017. Is agricultural extension positioned to promote agripreneurship in South Africa? S. Afr. J. Agric. Ext., 45(2):86-94.

SWANEPOEL, J.W., VAN NIEKERK, J.A. \& BLUM, M., 2016. Improving agribusiness of emerging small scale farmers through good management practices in pluralistic advisory systems. In Proceedings of the South African Society for Agricultural Extension. Centurion, South Africa.

VAN NIEKERK, J.A., GROENEWALD, I.B. \& ZWANE, E.M., 2014. Mentorship by commercial farmers in the land reform programme in Free State Province. S. Afr. J. Agric. Ext., 42(1):62-70.

VAN NIEKERK, J.A., STROEBEL, A., VAN ROOYEN, C.J., WHIFIELD, K.P. \& SWANEPOEL, C.J., 2011. Towards redesigning the agricultural extension service in South Africa: Views and proposal from extensionist in the Eastern Cape. S. Afr. J. Agric. Ext., 39(2):57-68.

VAN ROOYEN, C.J., 2014. Towards 2050: Trends and scenarios for African agribusiness. Int. Food. Agribus. Man., 17(Special Issue B):19-39.

VAN ROOYEN, C.J. \& NJOBE-MBULI, B., 1996. Access to land: Selecting the beneficiaries. In Agricultural land reform in South Africa: Policies, markets and mechanisms (pp.461498). Cape Town: Oxford University Press.

VAN ZYL, J., 1996. The farm size efficiency relationship. In Agricultural land reform in South Africa: Policies, markets and mechanisms (pp.259-309). Cape Town: Oxford University Press.

VETTER, S., 2003. What are the costs of land degradation to communal livestock farmers in South Africa: The case of Herschel district in the Eastern Cape. PhD Thesis, University of Cape Town.

WORTH, S.H., 2008. An assessment of the appropriateness of agricultural extension education in South Africa. PhD Thesis, University of KwaZulu-Natal.

ZWANE, E.M. \& KEKANA, E., 2014. The role of extension in agricultural development in Limpopo. Int. J. Agric. Ext., 2(2):147-152.

ZWANE, E.M., GROENEWALD, I.B. \& VAN NIEKERK, J.A., 2014. Critical factors influencing performance of extensionists in Limpopo Department of Agriculture in South Africa. S. Afr. J. Agric. Ext., 42(1):49-61. 
